\title{
Antihyperglycemic effects of Trigonella foenum-graecum seeds and Cinnamomum zeylanicum bark on key enzymes of carbohydrate metabolism in tissues of rats with experimental diabetes
}

\author{
Sapneh Sharma, Shiv Kumar Jayant, Vibhuti Mishra and Nalini Srivastava* \\ School of Studies in Biochemistry, Jiwaji University, India
}

\begin{abstract}
Diabetes is a life-threatening metabolic disorder worldwide. Type 1 diabetes results from the body's failure to produce insulin and requires the person to inject insulin. Recently, there has been increasing interest in treatment with medicinal plants. Therefore, the purpose of the study was to evaluate the effect of Trigonella foenumgraecum seeds and bark of Cinnamomum zeylanicum on level of blood glucose, insulin, glycogen and carbohydrate metabolic enzymes in experimental diabetes. Fiftyfour animals were used for present studies which were divided into nine groups. Diabetes was induced by intravenous injection of alloxan and diabetic rats were treated with three different doses of aqueous suspension Trigonella foenum-graecum seeds (440 mg/kg, $870 \mathrm{mg} / \mathrm{kg}$ and $1740 \mathrm{mg} / \mathrm{kg}$ body weight) and bark of cinnamomum zeylanicum $(100 \mathrm{mg} / \mathrm{kg}, 200 \mathrm{mg} / \mathrm{kg}$ and $400 \mathrm{mg} / \mathrm{kg}$ body weight) for 14 days. Levels of blood glucose and insulin were measured in control as well as diabetic rats on $14^{\text {th }}$ day. In addition, histological alteration and changes in key enzymes of carbohydrate metabolism also measured in diabetic rats. All parameters were compared with standard drug, glibenclamide. The results obtained showed that, oral administration of aqueous suspension of Trigonella foenum-graecum seeds and Cinnamomum zeylanicum bark powder to diabetic rats restored all the altered parameters to near normal in dose dependent manner. Our present study clearly revealed that Trigonella foenum-graecum seeds and cinnamomum zeylanicum bark possesses potent antihyperglycemic effect in experimental diabetic rats.
\end{abstract}

\section{Introduction}

Diabetes is a chronic metabolic disorder, prevalent in both developed and developing countries such as India. It is also a major endocrine disorder that affecting about $10 \%$ of the total population all over the world [1]. Diabetes results from insufficient amount or lack of insulin secretion or reduced sensitivity of the tissue to insulin [2,3]. Insulin insensitivity or insulin deficiency in diabetes mellitus leads to increase blood glucose level due to decrease in blood glucose utilization by the tissues such as liver, muscles and adipose tissues and increased glucose production in the liver. There are several pathogenetic processes which play important role in the development of diabetes because some of them involve killing of beta cells of pancreas with consequent insulin deficiency, and others in resistance to insulin action. Due to defect in the secretion or action of insulin on target tissues, abnormalities in carbohydrate, fat and protein metabolism do occur [4]. The exact cause of diabetes is unknown, although genetics and environmental factors such as obesity, fatty diet and lack of exercise, appear to play roles and might also influence the incidence of type 1 and type 2 diabetes mellitus. Diabetes can be associated with serious complications like neuropathy, nephropathy, retinopathy and even death. People with diabetes can lead an active life by managing the blood glucose level with drugs, insulin as well as by the lifestyle management which including dietary changes and physical activity, in order to prevent complications of disease.

Liver and muscles the two important tissues playing pivotal role in glucose homeostasis, are severely affected during diabetes mellitus, and have been shown to alter the activities of enzymes in the glycolytic, pentose phosphate, gluconeogenesis and glycogenolytic pathways [5]. Glucose homeostasis involves the coordinated regulation of catabolic and anabolic pathways as well as regulation of glycogen metabolism which is impaired defective or deficient insulin secretary response [4]. Carbohydrate metabolism highly affected in diabetes mellitus due to the insensitivity or insufficient amount of insulin because there are some key enzymes of carbohydrate metabolism which are directly or indirectly regulated by insulin [6]. Diabetes also changes the expression level of glucose transporters which regulate glucose utilization in tissues, and effect cellular processes [7]. In experimental diabetes, enzymes of glucose metabolism are markedly altered. One such enzyme is hexokinase that catalyses the conversion of glucose to glucose-6-phosphate and plays an important regulatory role in the maintenance of glucose homeostasis in the liver and other tissues. Being insulin regulated enzyme, the activity of hepatic hexokinase is inhibited due to the insulin deficiency in diabetes. Glucose-6-phosphatase also plays a key role in glucose homeostasis because it catalyses the both biochemical reaction of glycogenolysis and gluconeogenesis. Activation of gluconeogenic enzymes are observed in diabetes due to the insulin deficiency because under normal conditions, insulin acts as a suppressor

*Correspondence to: Nalini Srivastava, School of Studies in Biochemistry, Jiwaji University, Gwalior 474011, India, Tel: 91751 2442796/094253335703, Fax: 91 751 2341450, E-mail: nalinis21@yahoo.com

Key words: alloxan induced diabetes, trigonella foenum graecum, cinnamomum zeylanicum, carbohydrate metabolism, histopathology

Received: June 10, 2018; Accepted: June 25, 2018; Published: June 28, 2018 
Sharma S (2018) Antihyperglycemic effects of Trigonella foenum-graecum seeds and Cinnamomum zeylanicum bark on key enzymes of carbohydrate metabolism in tissues of rats with experimental diabetes

of gluconeogenic enzymes. Insulin decreases gluconeogenesis by reducing the activities of key enzymes, such as glucose-6-phosphatase, fructose-1, 6-bisphosphatase, phosphoenolpyruvate carboxykinase, and pyruvate carboxykinase [8].

The management of diabetes involves both the non-pharmacological and pharmacological approaches. The non-pharmacological approach includes exercise, diet control and surgery, while the pharmacological approach includes the use of drugs such as insulin, and oral hypoglycemic agents. The synthetic hypoglycemic drugs are not only expensive but also associated with serious side effects. Therefore, the focus has been shifted to herbal medicines which are not only easily available but also having no toxic effects on other body functions. Many herbal medicines which have antihyperglycemic potential have been recommended for the treatment of diabetes. A variety of ingredients present in medicinal plants have been tested and are found to have antihyperglycemic potential and thus shown therapeutic effects on diabetes and its complications.

More than 12000 plants have been described to be experimentally or ethnopharmacologically used in the treatment of diabetes and various plants extracts with medicinal values have been studied by many scientists in the field of diabetic research [9]. In present study two medicinal plants that are widely used to manage diabetes, Trigonella foenum graecum and Cinnamomum zeylanicum which are commonly known as fenugreek and cinnamon, respectively; are selected to study their effects on carbohydrate metabolism in diabetic rats. Both plants are well known for its pungent aroma and used as a spice and consumed regularly in Indian cuisine. Studies on different animal models have proved that fenugreek has strong antidiabetic properties. Several studies have demonstrated that fenugreek seed extract, mucilage of seeds, and leaves can decrease blood glucose levels in human and experimental diabetic animals $[10,11]$. Cinnamon, a natural product with long history of safety, is rich in polyphenolic components that have been shown to improve the antioxidant activities. Cinnamon belongs to the family Lauraceae, and its main components are cinnamaldehyde, cinnamic acid, tannin and Methylhydroxychalcone Polymer (MHCP). Cinnamon bark possesses significant anti-diabetic, anti-allergic, antiulcerogenic, antipyretic and antioxidant properties [12,13]. Both are being used as folk medicine not only in diabetes but also in number of other diseases.

The antihyperglycemic and antioxidant effect of Trigonella seed and Cinnamon bark have already been reported in previous studies [10-13]. The present study is planned to evaluate the protective effect of both Trigonella foenum-graecum seed, and Cinnamomum zelanicum bark in restoring the altered carbohydrate metabolism in alloxan induced diabetic rats. The standard antidiabetic drug, glibenclamide was taken as positive control.

\section{Material and methods}

\section{Chemicals}

Chemicals used in the present study were of highest purity/ analytical grade. Glucose, adenosine 5'-triphosphate, TRIS buffer, triethanolamine, Ethylenediaminetetraacetic acid, glycogen, D-glucose-6-phosphate, phosphoenol pyruvate, adenosine di phosphate, trichloroacetic acid, uridine diphosphate glucose, pyruvate kinase, lactate dehydrogenase, glibenclamide, Folin-Ciocalteu's reagent, glucose-6-phosphate dehydrogenase, glucose-6-phosphate, fructose 1,6 bis phosphate, 1-Amino, 2-Naphthol, 4-Sulfonic Acid (ANSA), nicotinamide adenine dinucleotide phosphate (reduced and oxidized) and magnesium chloride were purchased from HIMEDIA Chemicals, India. Alloxan monohydrate, beta mercaptoethanol were purchased from Sigma Aldrich Chemicals Private Limited, MO, USA. Rat insulin ELISA kit was purchased from Crystal Chem Inc.

\section{Experimental animals}

Adult male albino rats of Wistar strain (Rattus norvegicus) weighing about $140 \pm 10 \mathrm{~g}$ were used in the present study. Rats were obtained from the animal facilities of Defence Research and Development Establishment, Gwalior, India, and were maintained in a light (lightdark cycle of $12 \mathrm{~h}$ each) and temperature $\left(25^{\circ} \pm 2^{\circ} \mathrm{C}\right)$ controlled animal room of our department on standard pellet diet (obtained from Amrut Rat \& Mice Feed, New Delhi, India) and tap water ad libitum. Rats were acclimatized for one week prior to the start of the experiment.

\section{Experimental design}

Rats were randomly divided into nine groups of six rats each. Animals were divided into four groups and were given following treatments:

Group 1 : Control rats (healthy rats with normal blood glucose level)

Group 2: Diabetic control rats (i.v. injection of alloxan $55 \mathrm{mg} / \mathrm{kg}$ body weight)

Group 3 : Diabetic + Trigonella seed powder $(440 \mathrm{mg} / \mathrm{kg})$

Group 4 : Diabetic + Trigonella seed powder $(870 \mathrm{mg} / \mathrm{kg})$

Group 5 : Diabetic + Trigonella seed powder $(1740 \mathrm{mg} / \mathrm{kg})$

Group 6 : Diabetic + Cinnamon bark powder $(100 \mathrm{mg} / \mathrm{kg})$

Group 7 : Diabetic + Cinnamon bark powder $(200 \mathrm{mg} / \mathrm{kg})$

Group 8 : Diabetic + Cinnamon bark powder $(400 \mathrm{mg} / \mathrm{kg})$

Group $9:$ Diabetic + Glibenclamide $(0.6 \mathrm{mg} / \mathrm{kg})$

\section{Induction of experimental diabetes and Trigonella and Cinnamomum treatment}

Diabetes was induced in overnight fasted adult rats by single intravenous injection of $55 \mathrm{mg} / \mathrm{kg}$ body weight of alloxan monohydrate dissolved in normal saline $(0.85 \% \mathrm{NaCl})$ [14]. Diabetes was confirmed by blood glucose estimation after $48 \mathrm{~h}$ by an electronic glucometer. The rats with fasting glucose level above $300 \mathrm{mg} / \mathrm{dl}$ were considered diabetics and selected for the study.

Trigonella foenum-graecum (Tfg) seeds and Cinnamomum zeylanicum $(\mathrm{Cz})$ bark were purchased from the local herbal market, cleaned, dried and finely powdered. Aqueous suspension of both powdered $T f g$ seeds and $C z$ bark were prepared and three doses 440 $\mathrm{mg} / \mathrm{kg}, 870 \mathrm{mg} / \mathrm{kg}, 1740 \mathrm{mg} / \mathrm{kg}$ body weight [15] and $100 \mathrm{mg} / \mathrm{kg}$, $200 \mathrm{mg} / \mathrm{kg}, 400 \mathrm{mg} / \mathrm{kg}$ body weight [16] were given orally along with glibenclamide $0.6 \mathrm{mg} / \mathrm{kg}$ body weight [17] to the diabetic rats with the help of cannula, daily for two weeks.

\section{Collection of blood and tissues}

The blood was collected $24 \mathrm{~h}$ after the last treatment via ocular bleeding in tubes without EDTA for serum separation. After the blood collection, the rats were humanly killed by cervical dislocation; liver and brain tissues were excised off, washed with $0.9 \% \mathrm{NaCl}$ and used for different estimations. Animals were handled, ethically treated and humanly killed as per the rules and instructions of Ethical Committee of Animal Care of Jiwaji University, Gwalior, India, in accordance with the Indian National law on animal care and use. 
Sharma S (2018) Antihyperglycemic effects of Trigonella foenum-graecum seeds and Cinnamomum zeylanicum bark on key enzymes of carbohydrate metabolism in tissues of rats with experimental diabetes

\section{Estimation of insulin level}

Quantitative estimation of serum insulin was done by rat insulin ELISA kits using the manufacture's protocol. The sensitivity of the kit is $0.025 \mu \mathrm{g} / \mathrm{l}$. It is a solid phase two-site enzyme immunoassay which is based on the direct sandwich technique. The bound conjugate was detected by reaction with 3, 3', 5, 5'-tetramethylbenzidine. The reaction was stopped by adding acid and read at $450 \mathrm{~nm}$ in a microplate reader.

\section{Estimation of enzyme activities}

Hexokinase activity was estimated as described by Brandstrup [18]. In a $2.57 \mathrm{ml}$ reaction $\mathrm{mix}$, the final concentrations were 39 $\mathrm{mM}$ triethanolamine, $216 \mathrm{mM}$ D-glucose, $0.74 \mathrm{mM}$ ATP, $7.8 \mathrm{mM}$ magnesium chloride, $1.1 \mathrm{mMNADP}$ and 2.5 units glucose-6-phosphate dehydrogenase. Absorbance change per min was recorded for $5 \mathrm{~min}$ at $340 \mathrm{~nm}$. Specific activity is expressed as units/ mg protein. One unit will phosphorylate $1.0 \mu$ mole of D-glucose per minute at $25^{\circ} \mathrm{C}$.

Pyruvate kinase was assayed according to the method of Buchner and Pfleiderer [19]. The reaction mixture contained $0.2 \mathrm{mM}$ Tris$\mathrm{HCl}$ buffer ( $\mathrm{pH}$ 7.4), $0.1 \mathrm{mM} \mathrm{KCl}, 10 \mathrm{mM} \mathrm{MgCl}, 5 \mathrm{mM}$ ADP, $5 \mathrm{mM}$ phosphoenolpyruvate, 4 units $\mathrm{LDH}, 0.24 \mathrm{mM}$ NADH and suitably diluted enzyme protein. Change in absorbance was measured at 340 $\mathrm{nm}$ for $5 \mathrm{~min}$. Specific activity is expressed in $\mu$ mole NADH oxidized/ $\mathrm{min} / \mathrm{mg}$ protein.

Fructose 1,6 bis phosphatase activity was estimated by the method of Gancedo and Gancedo [20]. The assay mixture in a final volume of $2 \mathrm{ml}$ contained $1.2 \mathrm{ml}$ of Tris- $\mathrm{HCl}$ buffer $(0.1 \mathrm{M}, \mathrm{pH} 7.0), 0.1 \mathrm{ml}$ of fructose 1,6 bis phosphate $(0.05 \mathrm{M}), 0.25 \mathrm{ml}$ of magnesium chloride $(0.1 \mathrm{M}), 0.1 \mathrm{ml}$ of potassium chloride $(0.1 \mathrm{M}), 0.25 \mathrm{ml}$ of EDTA $(0.001$ $\mathrm{M})$ and $0.1 \mathrm{ml}$ of liver homogenate. The incubation was carried out at $37^{\circ} \mathrm{C}$ for $15 \mathrm{~min}$. The reaction was terminated by adding $1 \mathrm{ml}$ of $10 \%$ TCA. The suspension was centrifuged, and the supernatant was used for Pi estimation. Specific acticity is expressed as $\mu$ mole Pi formed/ $\mathrm{min} / \mathrm{mg}$ protein.

Glucose-6-phosphatase activity was assayed by the method of Koide and Oda [21]. Incubation mixture contained $0.7 \mathrm{ml}$ of citrate buffer ( $0.1 \mathrm{M}, \mathrm{pH} 6.2), 0.3 \mathrm{ml}$ of substrate glucose-6-phosphate (0.1 M), and $0.3 \mathrm{ml}$ of tissue homogenate. The reaction mixture was incubated at $37^{\circ} \mathrm{C}$ for $1 \mathrm{~h}$. Addition of $1 \mathrm{ml}$ of $10 \%$ TCA to the reaction tubes terminated the reaction. The suspension was centrifuged, and Pi was estimated. Specific activity is expressed as $\mu$ mole Pi formed/ $\mathrm{min} / \mathrm{mg}$ protein.

The Pi was determined by the method of Fiske and Subbarow [22] and concentration of inorganic phosphate was expressed as $\mu \mathrm{mole} / \mathrm{ml}$. Glycogen synthase activity was estimated by the method of Leloir and Goldemberg [23]. In a $3.10 \mathrm{ml}$ reaction mixure the final concentrations are $48 \mathrm{mM}$ Tris, $12.4 \mathrm{mM} \mathrm{MgCl} 2,1 \mathrm{mM}$ EDTA, $2.4 \mathrm{mM}$ 2-mercaptoethanol, 3.63 mM UDPG and 9.7 mM glucose 6-phosphate. Absorbance change per min was recorded for $5 \mathrm{~min}$ at $340 \mathrm{~nm}$. Specific activity is expressed as units/ mg protein. One unit will catalyze the incorporation of $1.0 \mu$ mole of glucose from UDP-glucose into glycogen per minute at $\mathrm{pH} 8.2$ at $30^{\circ} \mathrm{C}$, yielding $1.0 \mu$ mole of UDP which is measured in a $\mathrm{PK} / \mathrm{LDH} / \mathrm{NADH}$ system. Protein in the tissues samples was estimated by the method of Lowry et al. using bovine serum albumin as standard [24].

\section{Estimation of Glycogen content}

Glycogen was estimated in rat tissues by the method of Plummer et al. [25]. Glycogen levels were expressed in $\mathrm{mg} / \mathrm{g}$ tissue.

\section{Histopathological studies}

The liver, muscle and pancreas from the control, the untreated diabetic and the treated diabetic rats were collected at the time of sacrifice and washed with normal saline, transferred immediately to $10 \%$ formalene prepared in saline for paraffin embedding, sectioned and staining with Hematoxylin and Eosin followed by viewing at $100 \mathrm{X}$ magnification in light microscope [26].

\section{Statistical analyses}

Results are expressed as mean \pm S.E. of six sets of observations taken on different days. Statistical analyses were performed using Sigma Stat Statistical software version 2.0. All the statistical analyses were performed using one-way analysis of variance post hoc Bonferroni's multiple comparison test applied across the treatment groups. Significance was based on $P$ value $<0.05$.

\section{Results}

\section{Effect of oral administration of Tfg and $\mathrm{Cz}$ bark powder on the blood glucose level in control and diabetic rats}

The blood glucose level of all the rats was tested by taking the blood from the tail vein and using electronic glucometer. Effect of three different doses of $T f g$ seeds $(440 \mathrm{mg} / \mathrm{kg}, 870 \mathrm{mg} / \mathrm{kg}, 1740 \mathrm{mg} /$ $\mathrm{kg}$ body weight) and $C z$ bark $(100 \mathrm{mg} / \mathrm{kg}, 200 \mathrm{mg} / \mathrm{kg}$ and $400 \mathrm{mg} / \mathrm{kg}$ body weight) were studied on blood glucose level of alloxan induced diabetic rats. It was observed that oral administration of aqueous suspension of $T f g$ seed and $C z$ bark powder significantly decreased the blood glucose levels in diabetic rats. Results of the present study showed that oral administration of $440 \mathrm{mg} / \mathrm{kg}, 870 \mathrm{mg} / \mathrm{kg}, 1740 \mathrm{mg} /$ $\mathrm{kg}$ body weight, $T f g$ seed powder daily for 14 days, to the diabetic rats caused $3.0 \%, 6.3 \%$ and $16.6 \%$ decrease on $7^{\text {th }}$ day while $5.6 \%, 14.8 \%$ and $34.2 \%$ decrease in the blood glucose level on day $14^{\text {th }}$ of the start of treatmet. The $100 \mathrm{mg} / \mathrm{kg}, 200 \mathrm{mg} / \mathrm{kg}$ and $400 \mathrm{mg} / \mathrm{kg}$ body weight, $C z$ treatmemt to the diabetic rats showed $2.4 \%, 8.3 \%$ and $7.6 \%$ decrease on $7^{\text {th }}$ day and $9.1 \%, 18.1 \%$ and $20.6 \%$ decrease, respectively, in the blood glucose level on day $14^{\text {th }}$ when compared with day 0 (Table 1$)$. The standard drug glibenclamide $(0.6 \mathrm{mg} / \mathrm{kg}$ body weight $)$ which is used as a positive control, caused $23.2 \%$ decrease on $7^{\text {th }}$ day and $47.7 \%$ decrease on day $14^{\text {th }}$ when compared with 0 day. The results clearly showed the hypoglycemic potential of both $T f g$ seed and $C z$ bark.

\section{Effect of oral administration of Tfg seed and $\mathrm{Cz}$ bark powder on activities of glycolytic enzymes in the liver and the muscle tissue of diabetic rats}

The results of the present study clearly showed that alloxan adminstration in rats caused alteration in the activities of glycolytic enzymes namely, hexokinase and pyruvate kinase in both the liver and the muscle. The activiteis of hexokinase and pyruvate kinase were decreased by $58.8 \%$ and $42.2 \%$ in the liver and $45.0 \%$ and $47.7 \%$ in the muscle, respectively, when compared with control (Table 2). When the diabetic rats were given $440 \mathrm{mg} / \mathrm{kg}, 870 \mathrm{mg} / \mathrm{kg}, 1740 \mathrm{mg} /$ $\mathrm{kg}$ body weight $\mathrm{Tfg}$ treatment for two weeks, 3.9\%, $42.2 \%, 77.1 \%$ increase hexokinase activity and $13.1 \%, 23.1 \%, 48.4 \%$ increase in the activity of pyruvate kinase activity in the liver likewise $3.7 \%, 16.2 \%$, $54.7 \%$ increase hexokinase acitivity and $25.8 \%, 34.4 \%, 34.5 \%$ increase in pyruvate kinase activity in the muscle tissue, were observed when compared with untreated diabetic group (Table 2). Similarily when the $100 \mathrm{mg} / \mathrm{kg}, 200 \mathrm{mg} / \mathrm{kg}$ and $400 \mathrm{mg} / \mathrm{kg}$ body weight $C z$ treated diabetic rats were compared with untreated diabetic group, increase of activities of hexokinase and pyruvate kinase were $11.0 \%, 51.7 \%, 65.3 \%$ 
Sharma S (2018) Antihyperglycemic effects of Trigonella foenum-graecum seeds and Cinnamomum zeylanicum bark on key enzymes of carbohydrate metabolism in tissues of rats with experimental diabetes

Table 1. Effect of oral administration of different doses of aqueous suspensions of Trigonella foenum graecum and Cinnamomum zeylanicum for two weeks on blood glucose level of control and diabetic rats

\begin{tabular}{|l|l|l|l|}
\hline Groups & 0 Day & $\mathbf{7}^{\text {th }}$ Day & $\mathbf{1 4}^{\text {th }}$ Day \\
\hline Control & $80.8 \pm 4.5$ & $87.8 \pm 7.3^{\#}$ & $91.3 \pm 3.7^{\#}$ \\
\hline Diabetic & $305.2 \pm 5.4$ & $380.2 \pm 7.6^{* *}$ & $437.8 \pm 4.2^{* *}$ \\
\hline Diabetic $+T f g(440 \mathrm{mg} / \mathrm{kg})$ & $428.6 \pm 8.2$ & $415.6 \pm 9.5^{\#}$ & $404.6 \pm 9.2^{*}$ \\
\hline Diabetic $+T f g(870 \mathrm{mg} / \mathrm{kg})$ & $439.5 \pm 5.8$ & $411.7 \pm 2.2^{*}$ & $374.3 \pm 4.1^{* * *}$ \\
\hline Diabetic $+T f g(1740 \mathrm{mg} / \mathrm{kg})$ & $450.6 \pm 6.1$ & $375.8 \pm 3.2^{* *}$ & $296.5 \pm 2.8^{* * *}$ \\
\hline Diabetic $+C z(100 \mathrm{mg} / \mathrm{kg})$ & $372.8 \pm 7.2$ & $363.8 \pm 7.4^{\#}$ & $338.8 \pm 10.4^{*}$ \\
\hline Diabetic $+C z(200 \mathrm{mg} / \mathrm{kg})$ & $376.6 \pm 1.8$ & $345.3 \pm 1.7^{* *}$ & $308.3 \pm 2.7^{* * *}$ \\
\hline Diabetic $+C z(400 \mathrm{mg} / \mathrm{kg})$ & $387.0 \pm 1.8$ & $357.5 \pm 2.4^{* *}$ & $307.2 \pm 3.1^{* * *}$ \\
\hline Diabetic $+\mathrm{Gli}(0.6 \mathrm{mg} / \mathrm{kg})$ & $400.6 \pm 2.7$ & $307.2 \pm 2.6^{* * *}$ & $209.3 \pm 3.8^{* * *}$ \\
\hline
\end{tabular}

Blood glucose level was measured using electronic glucometer and is expressed as $\mathrm{mg} / \mathrm{dl}$. Results are mean \pm S.E. of six set of observation. $* \mathrm{P}<0.05, * * \mathrm{P}<0.001, * * * \mathrm{P}<0.0001$ and ${ }^{\#} \mathrm{P}>0.05$ when compared with control.

Diabetic rats were given aqueous suspension of powdered Trigonella foenum graecum seed and Cinnamomum zeylanicum bark orally at a dose of $440 \mathrm{mg} / \mathrm{kg}, 870 \mathrm{mg} / \mathrm{kg}, 1740 \mathrm{mg} / \mathrm{kg}$ body weight (Tfg) and $100 \mathrm{mg} / \mathrm{kg}, 200 \mathrm{mg} / \mathrm{kg}, 400 \mathrm{mg} / \mathrm{kg}$ body weight $(\mathrm{Cz})$, with the help of cannula, daily for two weeks. Glibenclamide (Gli) is taken as positive control and 0.6 $\mathrm{mg} / \mathrm{kg}$ body weight was given.

Table 2. Effect of oral administration of Trigonella foenum graecum and Cinnamomum zeylanicum for two weeks on the activities of glycolytic enzymes in the liver and the muscle of control and diabetic rats

\begin{tabular}{|c|c|c|c|}
\hline & Groups & Hexokinase & Pyruvate kinase \\
\hline \multicolumn{4}{|l|}{ Liver } \\
\hline & Control & $9.3 \pm 0.7$ & $2.3 \pm 0.1$ \\
\hline & Diabetic & $3.8 \pm 0.7^{* *}$ & $1.3 \pm 0.2 * *$ \\
\hline & Diabetic $+T f g(440 \mathrm{mg} / \mathrm{kg})$ & $3.9 \pm 0.7^{\#}$ & $1.5 \pm 0.2^{\#}$ \\
\hline & Diabetic $+T f g(870 \mathrm{mg} / \mathrm{kg})$ & $5.4 \pm 0.6^{\#}$ & $1.6 \pm 0.1^{\#}$ \\
\hline & Diabetic $+T f g(1740 \mathrm{mg} / \mathrm{kg})$ & $6.8 \pm 0.5^{* *}$ & $1.9 \pm 0.1^{*}$ \\
\hline & Diabetic $+C z(100 \mathrm{mg} / \mathrm{kg})$ & $4.2 \pm 0.6^{\#}$ & $1.4 \pm 0.2^{\#}$ \\
\hline & Diabetic $+C z(200 \mathrm{mg} / \mathrm{kg})$ & $5.8 \pm 0.6^{*}$ & $1.9 \pm 0.1^{*}$ \\
\hline & Diabetic $+C z(400 \mathrm{mg} / \mathrm{kg})$ & $6.3 \pm 0.5^{*}$ & $1.9 \pm 0.1^{*}$ \\
\hline & Diabetic + Gli $(0.6 \mathrm{mg} / \mathrm{kg})$ & $8.2 \pm 0.6^{* *}$ & $2.1 \pm 0.1 * *$ \\
\hline \multicolumn{4}{|l|}{ Muscle } \\
\hline & Control & $4.8 \pm 0.2$ & $1.8 \pm 0.1$ \\
\hline & Diabetic & $2.6 \pm 0.2 * * *$ & $0.9 \pm 0.1 * * *$ \\
\hline & Diabetic $+T f g(440 \mathrm{mg} / \mathrm{kg})$ & $2.7 \pm 0.2^{\#}$ & $1.2 \pm 0.1^{*}$ \\
\hline & Diabetic $+T f g(870 \mathrm{mg} / \mathrm{kg})$ & $3.1 \pm 0.2^{\#}$ & $1.2 \pm 0.1 * *$ \\
\hline & Diabetic $+T f g(1740 \mathrm{mg} / \mathrm{kg})$ & $4.1 \pm 0.1 * *$ & $1.5 \pm 0.1 * * *$ \\
\hline & Diabetic $+C z(100 \mathrm{mg} / \mathrm{kg})$ & $3.2 \pm 0.1^{*}$ & $1.1 \pm 0.1^{\#}$ \\
\hline & Diabetic $+C z(200 \mathrm{mg} / \mathrm{kg})$ & $3.7 \pm 0.1 * *$ & $1.4 \pm 0.1 * * *$ \\
\hline & Diabetic $+C z(400 \mathrm{mg} / \mathrm{kg})$ & $3.8 \pm 0.1^{* *}$ & $1.5 \pm 0.1^{* * *}$ \\
\hline & Diabetic + Gli $(0.6 \mathrm{mg} / \mathrm{kg})$ & $4.3 \pm 0.2 * *$ & $1.7 \pm 0.1^{* * *}$ \\
\hline
\end{tabular}

Specific activity of hexokinase is expressed as units $/ \mathrm{mg}$ protein. One unit will phosphorylate 1.0 umole of D-glucose per minute at $\mathrm{pH} 7.6$ at $25^{\circ} \mathrm{C}$

Specific activity of pyruvate kinase is expressed in $\mu$ mole NADH oxidized $/ \mathrm{min} / \mathrm{mg}$ protein. Results are mean \pm S.E. of six set of observation. $* \mathrm{P}<0.05$, $* * \mathrm{P}<0.001, * * * \mathrm{P}<0.000$ and ${ }^{\#} \mathbf{P}>0.05$ when compared with control

Diabetic rats were given aqueous suspension of powdered Trigonella foenum graecum seed and Cinnamomum zeylanicum bark orally at a dose of $440 \mathrm{mg} / \mathrm{kg}, 870 \mathrm{mg} / \mathrm{kg}, 1740 \mathrm{mg} / \mathrm{kg}$ body weight (Tfg) and $100 \mathrm{mg} / \mathrm{kg}, 200 \mathrm{mg} / \mathrm{kg}, 400 \mathrm{mg} / \mathrm{kg}$ body weight $(\mathrm{Cz})$, with the help of cannula, daily for two week.

Glibenclamide (Gli) is taken as positive control and $0.6 \mathrm{mg} / \mathrm{kg}$ body weight was given.

and $7.6 \%, 44.6 \%, 52.3 \%$, respectively, in the liver and $22.6 \%, 40.7 \%$, $43.3 \%$ and $9.6 \%, 48.3 \%, 61.2 \%$, respectively, in the muscle. The group given glibenclamide treatment, showed $114 \%, 61.5 \%$ increase in the activities of hexokinase and pyruvate kinase in the liver and $63.0 \%$, 79.5\% increase in the activities of muscle hexokinase and pyruvate kinase, respectively when compared with untreated diabetic group. The results clearly showed restoration of activities of key enzymes of glycolysis indicating restoration of glycolysis in diabetes by treatment with these plants.

\section{Effect of oral administration of Tfg seed and $\mathrm{Cz}$ bark powder on activities of gluconeogenic enzymes in the liver and the muscle tissue of diabetic rats}

The disturbance of glucose metabolism due to the diabetes was also confirmed by estimation of key enzymes of gluconeogenesis namely fructose 1,6 bis phosphatese and glucose-6-phosphatase in rat tissues. The results showed that there were significant increase in the activities of both the enzymes in the liver and the muscle of diabetic rats. The hepatic activities of fructose-1,6-bis phosphatase and glucose-6phosphatase were increased by $85.1 \%, 47.3 \%$ while $66.6 \%, 40 \%$ increase were observed in the muscle enzymes of diabetic rats when compared with control group. $\mathrm{Tfg}$ and $\mathrm{Cz}$ treatment for 15 days caused decrease in the activities of both the enzymes of diabetic rat tissues when compared with untreated group. Tfg treatment with three different doses $440 \mathrm{mg} / \mathrm{kg}, 870 \mathrm{mg} / \mathrm{kg}, 1740 \mathrm{mg} / \mathrm{kg}$ body weight caused $1.14 \%$, $8.0 \%, 32.1 \%$ decrease in the liver and $6.0 \%, 14.0 \%, 32.0 \%$ decrease in the muscles fructose-1,6-bis phosphatase activity while $3.5 \%, 10.7 \%$, $25.0 \%$ decrease in the liver and $4.7 \%, 9.5 \%, 19.1 \%$ decrease in the muscle glucose-6-phosphatse activity of diabetic rats when compared with diabetic group. Similarily $C z$ treatment with three different doses $100 \mathrm{mg} / \mathrm{kg}, 200 \mathrm{mg} / \mathrm{kg}, 400 \mathrm{mg} / \mathrm{kg}$ body weight caused $2.2 \%, 14.9 \%$, $24.1 \%$ decrease in the liver and $6 \%, 16 \%, 24 \%$ decrease in the muscle fructose-1,6-bis phosphatase activity while $1.1 \%, 7.1 \%, 10.7 \%$ decrease in the liver and $4.7 \%, 14.2 \%, 19.0 \%$ decrease in the muscle glucose 6 phosphatse activity of diabetic rats when compared with diabetic rats (Table 3). Glibenclamide treatment for the same period of time caused $42.5 \%, 36.0 \%$ decrease activity of fructose-1,6-bis phosphatase in the liver and the muscle and $28.5 \%, 23.8 \%$ decrease activity of glucose- 6 phosphatase in the liver and the muscle when compared with diabetic rats.

Table 3. Effect of oral administration of Trigonella foenum graecum and Cinnamomum zeylanicum for two weeks on the activities of gluconeogenic enzymes in the liver and the muscle of control and diabetic rats

\begin{tabular}{|c|c|c|c|}
\hline & Groups & $\begin{array}{l}\text { Fructose-1,6-bis } \\
\text { phosphatase }\end{array}$ & Glucose-6-phosphatase \\
\hline \multicolumn{4}{|l|}{ Liver } \\
\hline & Control & $0.47 \pm 0.01$ & $0.19 \pm 0.01$ \\
\hline & Diabetic & $0.87 \pm 0.02 * * *$ & $0.28 \pm 0.01 * * *$ \\
\hline & Diabetic $+T f g(440 \mathrm{mg} / \mathrm{kg})$ & $0.86 \pm 0.02^{\#}$ & $0.27 \pm 0.01 *$ \\
\hline & Diabetic $+T f g(870 \mathrm{mg} / \mathrm{kg})$ & $0.80 \pm 0.02 *$ & $0.25 \pm 0.01 * *$ \\
\hline & Diabetic $+T f g(1740 \mathrm{mg} / \mathrm{kg})$ & $0.59 \pm 0.01 * * *$ & $0.21 \pm 0.01 * * *$ \\
\hline & Diabetic $+C z(100 \mathrm{mg} / \mathrm{kg})$ & $0.85 \pm 0.02^{\#}$ & $0.28 \pm 0.01^{\#}$ \\
\hline & Diabetic $+C z(200 \mathrm{mg} / \mathrm{kg})$ & $0.74 \pm 0.01 * *$ & $0.26 \pm 0.01 * * *$ \\
\hline & Diabetic $+C z(400 \mathrm{mg} / \mathrm{kg})$ & $0.66 \pm 0.01 * * *$ & $0.25 \pm 0.01 * * *$ \\
\hline & Diabetic + Gli $(0.6 \mathrm{mg} / \mathrm{kg})$ & $0.50 \pm 0.01 * * *$ & $0.20 \pm 0.01 * * *$ \\
\hline \multicolumn{4}{|l|}{ Muscle } \\
\hline & Control & $0.30 \pm 0.01$ & $0.15 \pm 0.01$ \\
\hline & Diabetic & $0.50 \pm 0.01 * * *$ & $0.21 \pm 0.01 * * *$ \\
\hline & Diabetic $+T f g(440 \mathrm{mg} / \mathrm{kg})$ & $0.47 \pm 0.01^{\#}$ & $0.20 \pm 0.01 *$ \\
\hline & Diabetic $+T f g(870 \mathrm{mg} / \mathrm{kg})$ & $0.43 \pm 0.01 * *$ & $0.19 \pm 0.01 * * *$ \\
\hline & Diabetic $+T f g(1740 \mathrm{mg} / \mathrm{kg})$ & $0.34 \pm 0.01 * * *$ & $0.17 \pm 0.01 * * *$ \\
\hline & Diabetic $+C z(100 \mathrm{mg} / \mathrm{kg})$ & $0.47 \pm 0.01^{\#}$ & $0.20 \pm 0.01^{\#}$ \\
\hline & Diabetic $+C z(200 \mathrm{mg} / \mathrm{kg})$ & $0.42 \pm 0.01 * *$ & $0.18 \pm 0.01 * *$ \\
\hline & Diabetic $+C z(400 \mathrm{mg} / \mathrm{kg})$ & $0.38 \pm 0.01 * * *$ & $0.17 \pm 0.01 * *$ \\
\hline & Diabetic + Gli $(0.6$ mg/kg) & $0.32 \pm 0.01 * * *$ & $0.16 \pm 0.01 * * *$ \\
\hline
\end{tabular}

Specific activities of both enzymes fructose-1,6-bisphosphatase and glucose 6 phosphatase are expressed as $\mu$ mole $\mathrm{Pi}$ formed $/ \mathrm{min} / \mathrm{mg}$ protein.

Results are mean \pm S.E. of six set of observation. ${ }^{*} \mathrm{P}<0.05,{ }^{* *} \mathrm{P}<0.001, * * * \mathrm{P}<0.0001$ and ${ }^{\#} \mathrm{P}>0.05$ when compared with control.

Diabetic rats were given aqueous suspension of powdered Trigonella foenum graecum seed and Cinnamomum zeylanicum bark orally at a dose of $440 \mathrm{mg} / \mathrm{kg}, 870 \mathrm{mg} / \mathrm{kg}, 1740 \mathrm{mg} / \mathrm{kg}$ body weight (Tfg) and $100 \mathrm{mg} / \mathrm{kg}, 200 \mathrm{mg} / \mathrm{kg}, 400 \mathrm{mg} / \mathrm{kg}$ body weight $(C z)$, with the help of cannula, daily for two week.

Glibenclamide (Gli) is taken as positive control and $0.6 \mathrm{mg} / \mathrm{kg}$ body weight was given. 
Sharma S (2018) Antihyperglycemic effects of Trigonella foenum-graecum seeds and Cinnamomum zeylanicum bark on key enzymes of carbohydrate metabolism in tissues of rats with experimental diabetes

\section{Effect of oral administration of Tfg seed and $\mathrm{Cz}$ bark powder on glycogen content and activity of glycogen synthase in the liver and the muscle tissue of diabetic rats}

Studies were carried out to monitor the effect of diabetes on carbohydrate metabolism in which glycogen synthase and glycogen phosphorylase play key role. In this study we have evaluated the effect on activity of glycogen synthase and glycogen level in both the tissues of diabetic rats and also evaluate the protective effects of $T f g$ and $C z$ treatment. The activity of glycogen synthase decreased $56.9 \%$ in the liver and $49.0 \%$ in the muscle while glycogen level decreased $40.1 \%$ in the liver and $34.6 \%$ in the muscle tissue of diabetic rats compared with control.

Administration of $440 \mathrm{mg} / \mathrm{kg}, 870 \mathrm{mg} / \mathrm{kg}, 1740 \mathrm{mg} / \mathrm{kg}$ body weight Tfg seeds powder for 15 days showed increase activity of glycogen synthase by $12.1 \%, 20.2 \%, 46.4 \%$ in the liver while $3.5 \%, 7.1 \%, 28.5 \%$ in the muscle and glycogen level increased by $2.9 \%, 12.7 \%, 47.3 \%$ in the liver while $3.2 \%, 10.9 \% .39 .4 \%$ in the muscle, respectively of diabetic rats when compared with untreated diabetic group (Table 4).

The activity of glycogen synthase was increased by $19.1 \%, 79.7 \%$, $89.8 \%$ in the liver and $3.5 \%, 14.2 \%, 21.4 \%$ in the muscle similarly glycogen level was increased by $3.9 \%, 33.1 \%, 45.3 \%$ in the liver and $3.7 \%, 28.1 \%, 37.4 \%$ in the muscle of diabetic rats given $100 \mathrm{mg} / \mathrm{kg}$, $200 \mathrm{mg} / \mathrm{kg}, 400 \mathrm{mg} / \mathrm{kg}$ body weight $C z$ treatment for 2 weeks when compared with control group (Table 4). Treatment of glibenclamide for two weeks caused $98.9 \%$ and $71.4 \%$ decrease activity of glycogen synthase in the liver and the muscle respectively, while $62.3 \%, 50.5 \%$

Table 4. Effect of oral administration of Trigonella foenum graecum and Cinnamomum zeylanicum for two weeks on glycogen content and the activity of glycogen synthase in the liver and the muscle of control and diabetic rats

\begin{tabular}{|c|c|c|c|}
\hline & Groups & Glycogen synthase & Glycogen \\
\hline \multicolumn{4}{|l|}{ Liver } \\
\hline & Control & $2.30 \pm 0.14$ & $32.7 \pm 0.87$ \\
\hline & Diabetic & $0.99 \pm 0.10^{* * *}$ & $19.6 \pm 0.32 * * *$ \\
\hline & Diabetic $+T f g(440 \mathrm{mg} / \mathrm{kg})$ & $1.11 \pm 0.10^{*}$ & $20.2 \pm 0.30^{\#}$ \\
\hline & Diabetic $+T f g(870 \mathrm{mg} / \mathrm{kg})$ & $1.19 \pm 0.10^{*}$ & $22.1 \pm 0.13^{* *}$ \\
\hline & Diabetic $+T f g(1740 \mathrm{mg} / \mathrm{kg})$ & $1.45 \pm 0.08^{* *}$ & $28.8 \pm 0.14 * * *$ \\
\hline & Diabetic $+C z(100 \mathrm{mg} / \mathrm{kg})$ & $1.18 \pm 0.10^{\#}$ & $20.4 \pm 0.25^{\#}$ \\
\hline & Diabetic $+C z(200 \mathrm{mg} / \mathrm{kg})$ & $1.78 \pm 0.12^{* *}$ & $26.1 \pm 0.26^{* * *}$ \\
\hline & Diabetic $+C z(400 \mathrm{mg} / \mathrm{kg})$ & $1.88 \pm 0.10^{* *}$ & $28.4 \pm 0.14 * * *$ \\
\hline & Diabetic + Gli $(0.6 \mathrm{mg} / \mathrm{kg})$ & $1.97 \pm 0.10^{* * *}$ & $31.8 \pm 0.22 * * *$ \\
\hline \multicolumn{4}{|l|}{ Muscle } \\
\hline & Control & $0.55 \pm 0.02$ & $9.08 \pm 0.10$ \\
\hline & Diabetic & $0.28 \pm 0.01 * * *$ & $5.93 \pm 0.14 * * *$ \\
\hline & Diabetic + Tfg $(440 \mathrm{mg} / \mathrm{kg})$ & $0.29 \pm 0.01^{\#}$ & $6.12 \pm 0.13^{\#}$ \\
\hline & Diabetic $+T f g(870 \mathrm{mg} / \mathrm{kg})$ & $0.30 \pm 0.01 *$ & $6.58 \pm 0.19^{*}$ \\
\hline & Diabetic $+T f g(1740 \mathrm{mg} / \mathrm{kg})$ & $0.36 \pm 0.01 * *$ & $8.27 \pm 0.17 * * *$ \\
\hline & Diabetic $+C z(100 \mathrm{mg} / \mathrm{kg})$ & $0.29 \pm 0.01^{\#}$ & $6.15 \pm 0.13^{\#}$ \\
\hline & Diabetic $+C z(200 \mathrm{mg} / \mathrm{kg})$ & $0.32 \pm 0.01^{* *}$ & $7.60 \pm 0.13^{* * *}$ \\
\hline & Diabetic $+C z(400 \mathrm{mg} / \mathrm{kg})$ & $0.34 \pm 0.01 * *$ & $8.15 \pm 0.07 * * *$ \\
\hline & Diabetic + Gli $(0.6 \mathrm{mg} / \mathrm{kg})$ & $0.48 \pm 0.02 * * *$ & $8.93 \pm 0.09 * * *$ \\
\hline
\end{tabular}

Specific activity of glycogen synthase is expressed as units/ mg protein. One unit will catalyze the incorporation of $1.0 \mu \mathrm{mole}$ of glucose from UDP-glucose into glycogen per minute at $\mathrm{pH} 8.2$ at $30^{\circ} \mathrm{C}$

Level of glycogen expressed in $\mathrm{mg} / \mathrm{g}$ tissue.

Results are mean \pm S.E. of six set of observation. $* \mathrm{P}<0.05$, $* * \mathrm{P}<0.001, * * * \mathrm{P}<0.0001$ and ${ }^{\#} \mathrm{P}>0.05$ when compared with control.

Diabetic rats were given aqueous suspension of powdered Trigonella foenum graecum seed and Cinnamomum zeylanicum bark orally, $440 \mathrm{mg} / \mathrm{kg}, 870 \mathrm{mg} / \mathrm{kg}, 1740 \mathrm{mg} / \mathrm{kg}$ body weight $(T f g)$ and $100 \mathrm{mg} / \mathrm{kg}, 200 \mathrm{mg} / \mathrm{kg}, 400 \mathrm{mg} / \mathrm{kg}$ body weight $(\mathrm{Cz}$ ), with the help of cannula, daily for two weeks.

Glibenclamide (Gli) is taken as positive control and $0.6 \mathrm{mg} / \mathrm{kg}$ body weight was given. decrease in the glycogen content in the liver and the muscle of diabetic rats was observed when compared with untreated diabetic rats.

\section{Effect of oral administration of $\mathrm{Tfg}$ seed and $\mathrm{Cz}$ bark powder on serum insulin level of diabetic rats}

The results showed that there was significantly reduction in the insulin level of diabetic serum samples. It was observed that insulin level was decreased by $74.2 \%$ in the diabetic rats when compared with control. $T f g$ and $C z$ treatment for two weeks, caused increase in the levels of insulin in the dibetic rat serum when compared with untreated group. Treatment to the diabetic rats showed $161.9 \%$ recovery in the case of $T f g(1740 \mathrm{mg} / \mathrm{kg}$ body weight $)$ and $141.7 \%$ recovery in case of $C z$ ( $200 \mathrm{mg} / \mathrm{kg}$ body weight) while glibenclamide showed $220.2 \%$ recovery when compared with untreated diabetic group (Figure 1).

\section{Effect of oral administration of Tfg seeds and $\mathrm{Cz}$ bark powder on histology of pancreas, liver and the skeletal muscles of diabetic rats}

Pancreatic tissues of control animals showed normal distribution of islet of Langerhans within the exocrine part, islets were regular with well-defined boundaries. Diabetic pancreatic tissue showed shrinkage of islets Langerhans in size signs of necrosis of $\beta$-cell destruction. Reduction in number of islets along with diameter was observed in pancreatic tissue of diabetic rats. When diabetic animals treated with aqueous suspension of $T f g$ seed powder (1740 mg/kg body weight) and $C z$ bark powder $(200 \mathrm{mg} / \mathrm{kg}$ ) for two weeks showed islets cell look like normal tissue, also showed increase in size and diameter of islets of Langerhans (Figure 2). Number of islets were increased pancreatic tissue of diabetic rats treated with $\mathrm{T} f g$ and $C z$.

Skeletal muscle of control group showed normal architecture of myofibers while disorganized array of the myofiber structure, cell necrosis and myofibrillar discontinuation with loss of connections among myofibrils were observed in the skeletal muscle of diabetic rats (Figure 2). Treatment of aqueous suspension $T f g$ seed powder (1740 $\mathrm{mg} / \mathrm{kg}$ body weight) and $C z$ bark powder $(200 \mathrm{mg} / \mathrm{kg})$ to diabetic rats for two weeks, showed protection and was associated with normalization of skeletal muscle structural feature, which were similar to controls (Figure 2).

Liver of control animal showed normal cellular architecture with portal triad, central vein, numerous hepatocytes and sinusoidal lining. Liver of diabetic rats showed cellular abnormalities with area of vascular degeneration, necrosis, vascular congestion, cellular degeneration and pyknotic nuclei as compared with control group (Figure 2). Two-week treatment of $T f g$ seed powder $(1740 \mathrm{mg} / \mathrm{kg}$ body weight) and $C z$ bark powder $(200 \mathrm{mg} / \mathrm{kg}$ body weight) to diabetic animals showed recovery and restorative effect of the cellular components on the liver when compared with untreated diabetic group (Figure 2).

\section{Discussion}

Diabetic Mellitus (DM) is characteristic by hyperglycemia due to disturbance in the metabolism of carbohydrates, fat and protein, in which carbohydrate metabolism is highly affected at initial stage of diabetes. Chronic insulin deficiency and insulin insensitivity are the major causes of the decreased hepatic glucose utilization and increased glucose production, because insulin decreases the hepatic glucose output by activating glycogen synthesis and glycolysis, and by inhibiting gluconeogenesis. Alloxan is widely used to induce experimental diabetes in animals and their cytotoxic action is mediated by Reactive Oxygen Species (ROS). Alloxan and the product of its 


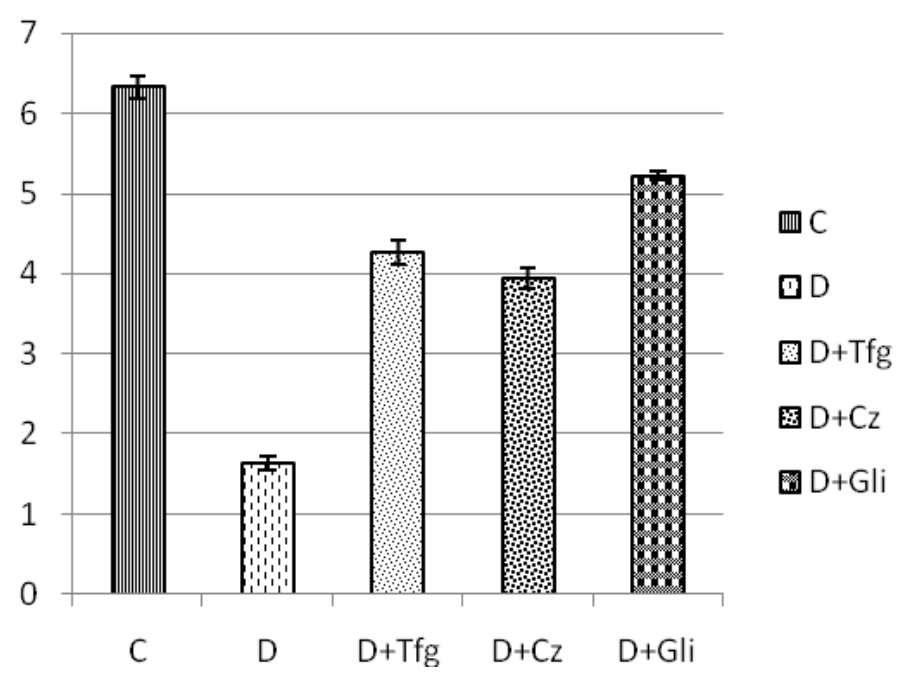

Figure 1. Serum insulin level $(\mu \mathrm{g} / \mathrm{l})$ in control and diabetic rats given treatment of aqueous extract of $T f g$ seeds and $C z$ bark powder for two weeks. C, control; D, diabetic; $\mathrm{D}+T f g$, diabetic rats receiving treatment of $1740 \mathrm{mg} / \mathrm{Kg}$ body weight Trigonella foenum graecum seed powder; $\mathrm{D}+\mathrm{Cz}$, diabetic rats receiving treatment of $200 \mathrm{mg} / \mathrm{kg}$ body weight Cinnamomum zeylanicum bark powder; $\mathrm{D}+\mathrm{Gli}$, diabetic rats receiving treatment of $0.6 \mathrm{mg}$ / $\mathrm{kg}$ body weight glibenclamide

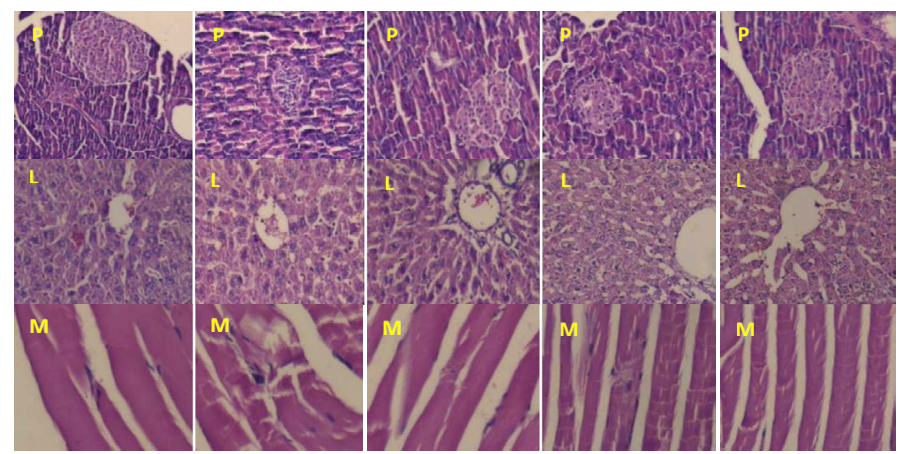

Figure 2. Histology of various tissues of control and treated rats $(\mathrm{H} \& \mathrm{E} \times 400)$. Figure $\mathrm{P} 1$, L1 and M1 shows normal histology of pancreas, liver and skeletal muscle of control rats respectively, P2, L2 and M2 shows various histological alterations in diabetic rats. P3, L3 and $\mathrm{M} 3$ receiving $T f g$ seed powder (1740 $\mathrm{mg} / \mathrm{kg}$ body wieght); P4, L4 and M4, receiving $\mathrm{Cz}$ bark powder ( $200 \mathrm{mg} / \mathrm{kg}$ body wieght); P5, L5 and M5, receiving glibenclamide (0.6 $\mathrm{mg} / \mathrm{kg}$ body weight) for two weeks.

P: Pancreas, L: Liver, M: Muscle ， 1: Control, 2: Diabetic, 3: Diabetic+ Tfg, 4: Diabetic $+C z$, 5: Diabetic + glibenclamide

reduction, dialuric acid, establish a redox cycle with the formation of superoxide radicals. The action of ROS with a simultaneous massive increase in cytosolic calcium concentration causes rapid destruction of beta cells [27].

In the present study, alloxan induced diabetic rats were chosen as the animal model because it resembles with many of the features of human type 1 diabetes mellitus. The present study was conducted to assess the antidiabetic potential of $T f g$ seeds and $C z$ bark and protection if any, against altered carbohydrate metabolism in diabetic rats. The results showed that, diabetic rats exhibited a significant increase in plasma glucose level while daily administration of aqueous suspension of seed and bark powder of both plants with three different doses for two weeks resulted in dose-dependent and time-dependent decrease in the blood glucose levels in diabetic rats. The decrease in blood glucose level ranged from $3 \%$ to $17 \%$ and $6 \%$ to $34 \%$ on day 7 and day 14, respectively, when given in different doses of $T f g$ seeds while $\mathrm{C} z$ treated group showed $2 \%$ to $8 \%$ and $9 \%$ to $21 \%$ decrease in the blood glucose levels on day $7^{\text {th }}$ and $14^{\text {th }}$, respectively. In the group given glibenclamide, the decrease in blood glucose level was $23 \%$ and $48 \%$ on day $7^{\text {th }}$ and $14^{\text {th }}$, respectively.

The increased glucose level might be due to the fact that alloxan causes notable reduction in insulin release due to destruction of the pancreatic $\beta$-cells. The possible mechanism of hypoglycemic action of $T f g$ seeds and $C z$ bark may be through regulation of pancreatic cells and potentiation of pancreatic secretion of insulin from beta cells and / or due to enhanced transport of blood glucose to the peripheral tissue. The insulin level was significantly decreased in alloxan induced diabetic rats due to the destruction of $\beta$-cells of pancreas which is clearly seen in histological studies. Oral administration of $T f g$ and $C z$ significantly restored the insulin level in serum of diabetic rats when compared with untreated group.

The increased level of insulin in $T f g$ and $C z$ treated diabetic rats may be due to their insulin secreatagouge activity causing the activation of remnant $\beta$-cells in the pancreas, which was in accordance with the observed histological observations.

The present study showed histopathological changes after alloxan injection, represented by destructed beta cells of pancreatic acini. Moreover, alloxan administration elicited morphological changes in liver and skeletal muscles of diabetic rats with severe damage of hepatocytes and myofibers. These results corroborate the finding of other workers [28-30]. When diabetic rats were treated with Tfg seeds and $C z$ bark powder, recovery has been observed in pancreas, liver and muscles. The active compounds of both plants 4-hydroxyisoleucin and cinnamaldehyde of $T f g$ and $C z$, giving protection against diabetic complications respectively, may be involved at histopathological level.

Liver is the main site for glycolysis and gluconeogenesis the two important complementary pathways that balance the glucose levels in the body [31]. Glucose homeostasis is highly affected in diabetes due to insulin deficiency/ insensitivity resulting in hypoglycemica [32]. Alloxan injection caused destruction of pancreatic beta cells and increased blood glucose level by reduction in insulin secretion. Insulin influences the intracellular glucose utilization in a number of ways, including increased hepatic glycolysis by increasing the activity and amount of several key enzymes. In the present study the significantly decreased activities of hexokinase and pyruvate kinase observed in diabetic rats indicated decreased rate of glycolysis under diabetic condition in the insulin dependent tissue (skeletal muscle) and insulin independent tissue (liver). Decreased hexokinase activity also indicates decreased availability of glucose-6-phosphate for the proper operation of HMP shunt under diabetic condition. A similar pattern of decreased glycolytic enzyme activities was reported in diabetic animals earlier also [33]. Administration of aqueous suspension of $T f g$ and $C z$ to diabetic rats significantly increased the activities of hexokinase and pyruvate kinase in the liver and the skeletal muscle. Glucose transport inside te cells may be facilitated by $T f g$ seeds and $C z$ bark powder, which in turn stimulate the activity of these enzymes. $T f g$ and $C z$ help in restoring the activities of glycolytic enzymes thus normalizing the energy supply in diabetic rats.

Glucose-6-phosphatase, the enzyme of glucose homeostasis catalyses the ultimate step of both glycogenolysis and gluconeogenesis and fructose-1, 6-bisphosphatase, one of the important regulatory enzymes of gluconeogenesis, are affected by diabetes. Diabetic condition leads to an increase in the levels of these enzymes [34,35]. The increased activities of glucose 6-phosphatase and fructose-1, 6 bisphosphatase in both liver and muscles of the diabetic rats, may be due to insulin insufficiency. In the present study, a marked decrease in the activities of 
Sharma S (2018) Antihyperglycemic effects of Trigonella foenum-graecum seeds and Cinnamomum zeylanicum bark on key enzymes of carbohydrate metabolism in tissues of rats with experimental diabetes

glucose-6-phosphatase and fructose 1,6 bisphosphatase was observed after the oral administration of suspension of both $T f g$ seeds and $C z$ bark powder for two weeks indicated that gluconeogenesis is inhibited in treated diabetic rats contributing to their antihyperglycemic effects.

Diabetes mellitus is known to impair the normal capacity of muscle and liver to synthesize glycogen. Liver and muscle glycogen content was significantly reduced in diabetic rats. Glycogen is the primary intracellular storage form of glucose and its levels in various tissues are a direct reflection of insulin activity as insulin promotes intracellular glycogen deposition by stimulating glycogen synthase and inhibiting glycogen phosphorylase. Since alloxan causes damage to pancreatic beta cells with concomitant decrease in insulin levels, it is obvious that glycogen levels in tissues especially liver and muscle, decrease as they depend on insulin for intracellular transport of glucose. In general, increased hepatic glucose production, plus decreased hepatic glycogen synthesis and glycolysis, are the major sites that result in hyperglycemia. Glycogen synthase is the key enzyme involved in the synthesis of glycogen from glucose in the skeletal muscle as well as in the liver $[35,36]$. Reduction in glycogen synthase and a concomitant elevation in the glycogen phosphorylase activities during diabetic condition have been reported [37-39]. Our results collaborate the earlier findings. The restoration of the depleted glycogen levels in the tissues of $T f g$ and $C z$ treated animals, may due to increased insulin level resulting in restoration of activity of glycogen synthase. In the present study we observed changes in insulin level along with glycogen synthase activity in diabetic rats which were restored to some extent on treatment with both $T f g$ and $C z$.

Defects in carbohydrate metabolizing machinery and consistent efforts of the physiological systems to recover the imbalance in carbohydrate metabolism place an overstress on the endocrine system, which leads to the deterioration of endocrine control. Continuing deterioration of endocrine control causes the metabolic disturbances. Treatment of $T f g$ and $C z$ to diabetic rats showed protection against diabetes induced alteration in carbohydrate metabolism.

\section{Conclusion}

It can be concluded from the present study that $T f g$ and $C z$ have protective effects on restoring glucose level, carbohydrate metabolic enzymes and histological changes in alloxan induced diabetic rats. This establishes the efficacy of both the plants in the maintenance of glucose homeostasis which may be used as therapeutic agents in the management of diabetes. Further studies are required to find out the exact mechanism of hypoglycemic action of the Trigonella foenum graecum seed and Cinnamomum zeylanicum bark powder.

\section{Acknowledgement}

The financial supports of Department of Science and Technology, New Delhi, India, in the form of FIST Grant to the School, and Madhya Pradesh Council of Science and Technology, Bhopal, India, in the form of individual research project to Nalini Srivastava, are thankfully acknowledged.

\section{References}

1. Shaw JE, Sicree RA, Zimmet PZ (2010) Global estimates of the prevalence of diabetes for 2010 and 2030. Diabetes Res Clin Pract 87: 4-14. [Crossref]

2. Georg P, Ludvik B (2000) Lipids and Diabetes. J Clin Basic Cardiol 3: 159-162.

3. Nyholm B, Porksen N, Juhl CB, Gravholt CH, Butler PC, et al. (2000) Assessment of insulin secretion in relatives of patients with type2 non-insulin dependent diabetes mellitus: evidence of early beta-cell dysfunction. Metabolism 49: 896-905.
4. Aronoff SL, Berkowitz K, Shreiner B, Want L (2004) Glucose metabolism and regulation: beyond insulin and glucagon. Diabetes Spectr 17: 183-190.

5. McAnuff MA, Omoruyi FO, Morrison EY, Asemota HN (2005) Changes in some liver enzymes in streptozotocin-induced diabetic rats fed sapogenin extract from bitter yam (Dioscorea polygonoides) or commercial diosgenin. West Indian Med J 54: 97-101. [Crossref]

6. Havel JP (2004) Update on adipocyte hormones: Regulation of energy balance and carbohydrate/lipid metabolism. Diabetes 53: 143-151. [Crossref]

7. Herman MA, Kahn BB (2006) Glucose transport and sensing in the maintenance of glucose homeostasis and metabolic harmony. J Clin Invest 116: 1767-1775. [Crossref]

8. Edgerton DS, Ramnanan CJ, Grueter CA, Johnson KM, Lautz M, et al. (2009) Effects of insulin on the metabolic control of hepatic gluconeogenesis in vivo. Diabetes 58: 2766-2775. [Crossref]

9. Bnouham M, Ziyyat A, Mekhfi H, Tahri A, Legssyer A (2006) Medicinal plants with potential antidiabetic activity. A review of ten years of herbal medicine research (19902000). Int J Diabetes Metab 14: 1-25.

10. Sharma S, Mishra V, Jayant SK, Srivastava N (2015) Effect of Trigonella foenum graecum L on the Activities of Antioxidant Enzyme and Their Expression in Tissues of Alloxan-Induced Diabetic Rats. J Evid Based Complementary Altern Med 20: 203 211. [Crossref]

11. Sharma S, Mishra A (2017) Effects of bark of Cinnamomum Zeylanicum on hyperglycemia induced oxidative stress and DNA damage in experimental diabetic rats. Int J Pharm Bio Sci 8: 461-470.

12. Arshadi S, Azarbayjani MA, Hajaghaalipor F, Yusof A, Peeri M, et al. (2015) Evaluation of Trigonella foenum-graecum extract in combination with swimming exercise compared to glibenclamide consumption on type 2 Diabetic rodents. Food Nutr Res 59: 29717. [Crossref]

13. Rao PV, Gan SH (2014) Cinnamon: a multifaceted medicinal plant. Evid Based Complement Alternat Med 2014: 642942. [Crossref]

14. Gul N, Cebesoy D, Ozsoy N (2008) Lectins binding during alloxaninduced diabetes in rat soleus muscle. Afr J Biotechnol 7: 926-930.

15. Xue W, Lei J, Li X, Zhang R (2011) Trigonella foenum graecum seed extract protects kidney function and morphology in diabetic rats via its antioxidant activity. Nutr Res 31: 555-562. [Crossref]

16. Hassan SA, Barthwal R, Nair MS, Haque SS (2012) Aqueous Bark Extract of Cinnamomum Zeylanicum: A Potential Therapeutic Agent for Streptozotocin induced Type 1 Diabetes Mellitus (T1DM) Rats. Trop J Pharm Res 11: 429-435.

17. Kumari KS, Immanuel G, Dhanya BS (2012) Evaluation of the effect of tigogenin on the activities of certain key enzymes of carbohydrate metabolism in streptozotocin induced diabetic rats. Int J Biol Med Res 3: 1242-1247.

18. Brandstrup N, Kirk JE, Bruni C (1957) The hexokinase and phosphoglucoisomerase activities of aortic and pulmonary artery tissue in individuals of various ages. $J$ Gerontol 12: 166-171. [Crossref]

19. Bucher T, Pfleiderer G (1955) Pyruvate kinase from muscle. In Colowick, S. P. and Kaplan, N. O. (eds), Methods Enzymol. Academic Press, London, 1: 435-440.

20. Gancedo JM, Gancedo C (1971) Fructose-1, 6-diphosphatase, phosphofructokinase and glucose-6-phosphate dehydrogenase from fermenting and nonfermenting yeasts. Arch Microbiol 76: 132-138. [Crossref]

21. Koide H, Oda T (1959) Pathological occurrence of glucose-6-phosphatase in serum in liver diseases. Clin Chim Acta 4: 554-561. [Crossref]

22. Fiske CH, Subbarow J (1925) The colorimetric determination of phosphorus. J Biol Chemist 66: 375-400.

23. Leloir LH, Goldemberg SH (1960) Synthesis of glycogen from uridine diphosphate glucose in liver. J Biol Chem 235: 919-923. [Crossref]

24. LOWRY OH, ROSEBROUGH NJ, FARR AL, RANDALL RJ (1951) Protein measurement with the Folin phenol reagent. J Biol Chem 193: 265-275. [Crossref]

25. Plummer TD (1897) An Introduction to Practical Biochemistry. Tata Mc Graw Hill Company, UK, Whittington.

26. Szkudelski T (2001) The mechanism of alloxan and streptozotocin action in B cells of the rat pancreas. Physiol Res 50: 537-546. [Crossref] 
Sharma S (2018) Antihyperglycemic effects of Trigonella foenum-graecum seeds and Cinnamomum zeylanicum bark on key enzymes of carbohydrate metabolism in tissues of rats with experimental diabetes

27. Guo X, Li H, Xu H, Woo S, Dong H, et al. (2012) Glycolysis in the control of blood glucose homeostasis. Acta Pharmaceutica Sinica 2: 358-367.

28. Hamid MA, Moustafa N (2013) Protective effect of curcumin on histopathology and ultrastructure of pancreas in the alloxan treated rats for induction of diabetes. $J$ Basic Appl Zool 66: 169-179.

29. Lucchesi AN, Cassettari LL, Spadella CT (2015) Alloxan-Induced Diabetes Causes Morphological and Ultrastructural Changes in Rat Liver that Resemble the Natural History of Chronic Fatty Liver Disease in Humans. J Diabetes Res.

30. Izumiya Y, Hopkins T, Morris C, Sato K, Zeng L, et al. (2008) Fast/Glycolytic Muscle Fiber Growth Reduces Fat Mass and Improves Metabolic Parameters in Obese Mice. Cell Metab 7: 159-172. [Crossref]

31. Guo X, Li H, Xu H, Woo S, Dong H, et al. (2012) Glycolysis in the control of blood glucose homeostasis. Acta Pharmaceutica Sinica 2: 358-367.

32. Bano G (2013) Glucose homeostasis, obesity and diabetes. Best Pract Res Clin Obste Gynaecol 27: 715-726. [Crossref]

33. Moore MC, Coate KC, Winnick JJ, An Z, Cherrington AD (2012) Regulation of hepatic glucose uptake and storage in vivo. Adv Nutr 3: 286-294. [Crossref]
34. Xia X, Yan J, Shen Y, Tang K, Yin J, et al. (2011) Berberine Improves Glucose Metabolism in Diabetic Rats by Inhibition of Hepatic Gluconeogenesis. PLoS 6 : e16556. [Crossref]

35. Jayaprasad B, Sharavanan PS, Sivaraj R (2016) Antidiabetic effect of Chloroxylon swietenia bark extracts on streptozotocin induced diabetic rats. Beni-Seuf Univ J Appl Sci 5: 61-69.

36. Rao PV, Madhavi K, Naidu MD, Gan SH (2013) Rhinacanthus nasutus Improves the Levels of Liver Carbohydrate, Protein, Glycogen, and Liver Markers in StreptozotocinInduced Diabetic Rats. Evid Based Complement Alternat Med 2013: 102901. [Crossref]

37. Weksler YL, Olga Gotlibovitz O, Stark AH, Madar Z (2001) Diet and diabetic state modify glycogen synthase activity and expression in rat hepatocytes. $J$ Nutr Biochem 12: 458-464. [Crossref]

38. Henriksen EJ, Teachey MK (2007) Short-term in vitro inhibition of glycogen synthase kinase 3 potentiates insulin signaling in type I skeletal muscle of Zucker Diabetic Fatty rats. Metabolism 56: 931-938. [Crossref]

39. Bollen M, Hue L, Stalmans W (1983) Effects of glucose on phosphorylase and glycogen synthase in hepatocytes from diabetic rats. Biochem J 210: 783-787. [Crossref]

Copyright: $(02018$ Sharma S. This is an open-access article distributed under the terms of the Creative Commons Attribution License, which permits unrestricted use, distribution, and reproduction in any medium, provided the original author and source are credited. 